Rakenteiden Mekaniikka (Journal of Structural Mechanics)

Vol. 50, No 3, 2017, pp. 179 - 181

https://rakenteidenmekaniikka.journal.fi/index

https://doi.org/10.23998/rm.64740

(c) The author(s) 2017.

Open access under CC BY-SA 4.0 license.

\title{
Nodular cast iron ONERA fatigue model fitting
}

\author{
Asko Kumpula ${ }^{1}$, Joona Vaara, Anton Leppänen and Tero Frondelius
}

Summary. ONERA fatigue model identification has been carried out for the nodular cast iron material. Selected fatigue model considers mean stress effect, temperature dependency, multiaxiality and non-linear damage cumulation due to variable amplitude loading. Fitting of model parameters was carried out using the Z-set software package.

Key words: fatigue, nodular cast iron, cylinder head, ONERA fatigue model

Received 13 June 2017. Accepted 7 August 2017. Published online 21 August 2017.

\section{Introduction}

Mechanical properties of nodular cast iron are dependent on the casting process. It is important to know the fatigue properties of different microstructures formed in the casting process and how material properties are distributed locally in the actual component. This is especially emphasized in large castings. The test specimens for fatigue testing were manufactured so that the desired pearlite fraction in the micro structure was achieved. An extensive fatigue test program was executed and the model was fit to the test results. During the product development process [4], the identified model has given good predictions for cylinder head lifetimes as shown in reference [5].

\section{Fatigue model calibration}

ONERA fatigue model $[1,2,3,6]$ was fit to observed $\mathrm{S}-\mathrm{N}$ test data results using Z-set software package. Equation for number of cycles to failure $N_{f}(1)$ was simulated and model coefficients were fit so that the $\mathrm{S}-\mathrm{N}$ curve lies on the top of the test data, reflecting the median behavior. The equation for $N_{f}$ is [2]:

$$
N_{f}=\frac{\left\langle\sigma_{u}-\sigma_{\max }\right\rangle}{\left\langle\sigma_{a}-\sigma_{l}(\bar{\sigma})\right\rangle}\left[\frac{\sigma_{a}}{M(\bar{\sigma})}\right]^{-\beta},
$$

where $\sigma_{u}$ is the ultimate tensile strength and $\sigma_{\max }$ is the maximum stress of the cycle. $\sigma_{a}$ is the stress amplitude. Parameter $\beta$ controls the slope of the S-N curve. Convention \langle\rangle

${ }^{1}$ Corresponding author. asko.kumpula@wartsila.com 
denotes the Macaulay brackets, $\langle x\rangle=0$ if $x<0$ and $\langle x\rangle=x$ if $x>0$. Function $\sigma_{l}(\bar{\sigma})$ defines the mean stress dependency of fatigue limit $\sigma_{l}$ such that:

$$
\sigma_{l}(\bar{\sigma})=\frac{\sigma_{l 0}}{1+b_{1} \bar{\sigma}}
$$

where $\sigma_{l 0}$ is the fatigue limit at $R=\sigma_{\min } / \sigma_{\max }=-1, \bar{\sigma}$ is the mean stress, and $b_{1}$ is a model parameter. Function $M(\bar{\sigma})$ defines the mean stress dependency of S-N curve shift along $\mathrm{N}$-axis such that:

$$
M(\bar{\sigma})=\frac{M_{0}}{1+b_{2} \bar{\sigma}}
$$

where $M_{0}$ controls the $\mathrm{S}-\mathrm{N}$ curve position along cycle axis at $R=\sigma_{\min } / \sigma_{\max }=-1, \bar{\sigma}$ is the mean stress, and $b_{2}$ is a model parameter.

\section{Results}

Identified model at the room temperature with $R=-1$ has been illustrated in the Figure 1. For confidentality reasons amplitude axis in the figure has been normalized. Lifetime of the material is strongly dependent on the amount of pearlite in the microstucture.

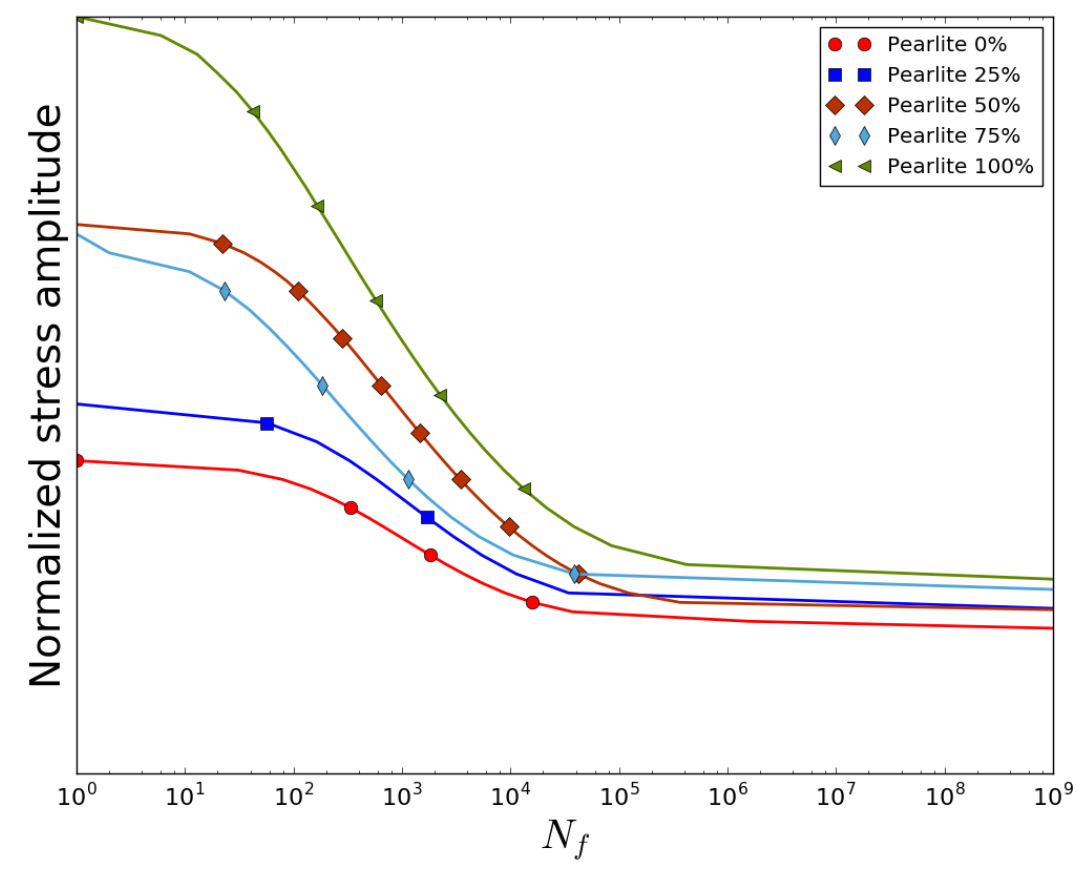

Figure 1. Identified room temperature S-N -curves for pearlite fractions of $0 \%, 25 \%, 55 \%, 75 \%$ and $100 \%$. Curves are normalized.

\section{Conclusions}

The amount of pearlite in the microstructure of large castings may vary due to manufacturing conditions. Fatigue testing revealed that lifetime of the material is strongly dependent on the pearlite fraction. Therefore it is important to take into account the 
local material properties in larger castings. Casting simulation can be used to predict the amount of pearlite in the microstructure formed in the manufacturing process. Identified model can then be used in correct areas allowing more accurate lifetime predictions.

\section{References}

[1] ONERA lifetime prediction model. http://zset-software.com/wordpress/ wp-content/uploads/trainings/Onera_lifetime_model_training.pdf. Accessed: 2017-06-01.

[2] Z-set user manual. User commands version 8.6. http://zset-software.com/ wordpress/wp-content/uploads/manuals/z_set_user.pdf. Accessed: 2017-05-29.

[3] J. L. Chaboche and P. M. Lesne. A non-linear continuous fatigue damage model. Fatigue $\&$ Fracture of Engineering Materials \& Structures, 11(1):1-17, 1988. ISSN 1460-2695. URL https://doi.org/10.1111/j.1460-2695.1988.tb01216.x.

[4] Juho Könnö, Hannu Tienhaara, and Tero Frondelius. Wärtsilä digital design platform. Rakenteiden Mekaniikka, 50(3):234-238, 2017. URL https ://doi .org/10.23998/rm. 64621.

[5] Anton Leppänen, Asko Kumpula, Joona Vaara, Massimo Cattarinussi, Juho Könnö, and Tero Frondelius. Thermomechanical fatigue analysis of cylinder head. Rakenteiden Mekaniikka, 50(3):182-185, 2017. URL https://doi.org/10.23998/rm.64743.

[6] Miikka Väntänen, Joona Vaara, Jukka Aho, Jukka Kemppainen, and Tero Frondelius. Bayesian sequential experimental design for fatigue tests. Rakenteiden Mekaniikka, 50 (3):201-205, 2017. URL https://doi.org/10.23998/rm.64924.

Asko Kumpula, Joona Vaara, Anton Leppänen, and Tero Frondelius

Wärtsilä

Järvikatu 2-4

65100 Vaasa

asko.kumpula@wartsila.com, joona.vaara@wartsila.com, anton.leppanen@wartsila.com, tero.frondelius@wartsila.com 